\title{
Education and training in Italy: Status and transitions
}

\author{
Simona Savelli \\ Facoltà di Scienze della Formazione, Università degli Studi Guglielmo Marconi, Italia, Roma
}

\section{Email address:}

simsavit@gmail.com

\section{To cite this article:}

Simona Savelli. Education and Training in Italy: Status and Transitions. Education Journal. Vol. 3, No. 6, 2014, pp. 323-339. doi: $10.11648 /$ j.edu.20140306.12

\begin{abstract}
This paper describes the current Italian System of Education and Training (the Scuola dell'Infanzia, the Primo Ciclo di Istruzione, the Secondo Ciclo di Istruzione, the Istruzione Superiore, the Formazione Professionale Iniziale, the Apprendistato, the Istruzione e Formazione degli Adulti, the Formazione Continua) and summarizes the actions that the Government has recently undertaken in the fields of Education, Training and Employment.
\end{abstract}

Keywords: Education, Employment, Italy, Training

\section{Introduction}

The National Education and Training ${ }^{1}$ System is constantly crossed by the winds of reform. Society is in a perpetual change. Culture, Technology and Economy with it, provide multidimensional pressures that give a boost to the fields of Pedagogy and Didactics and to the entire Structural Order. These, in turn, act in a decisive way on the daily lives of each of us and on the development of entire countries, like ours, in an infinitive game of references.

In this ever-changing situation we intend to draw a picture of the structure and functioning of the current Italian System of Education and Training in its connection with the Employment dimension.

In view of the evidence also emerged from the constant collaboration with the Member States of the European Union, Italy is moving towards a greater clarity and transparency of Educational paths and a structural articulation that allows, at the same time, greater flexibility and internal permeability and a greater transnational mobility.

The concept of Competence, as highlighted in previous papers, has become an integral part of the entire Education and Training landscape, in close liaison with the Credit Recognition System, which is its driving-force.

In tandem with Accreditation it moves Quality Certification, which permeates and crosses the entire sphere of Education, Training and Employment.

Special attention is currently given to Technical and

${ }^{1}$ For a conceptual distinction among the Italian terms Educazione, Istruzione and Formazione on the basis of the Italian socio-cultural heritage, please refer to [15].
Vocational Training, a sector in which the Regioni ${ }^{2}$ play a crucial role, also because of their close contact with the needs of the territory.

For the purposes of a greater intelligibility at the international level, this paper follows a certain order taken from a recently published paper which is the result of a research conducted on the United States Education and Training System ${ }^{3}$.

With regard to the United States context they were taken into consideration: the role of the Federal State and the Federated States; accreditation of Educational Institutions; articulation of Primary and Secondary Education; the Credit System; Post-Secondary Education (the role of the Federal States; standard and credits; institutional and programmatic accreditation; articulation of Post-Secondary Education) ${ }^{4}$.

The structure just outlined has been attuned with the data and information emerging from the major National and European updated documents currently available on the Italian Education and Training System, including:

- the First Italian Report Referencing Qualifications to the European Qualification Framework (EQF), as a result of the Agreement among the State, Regions and Autonomous Provinces, of 2012;

\footnotetext{
${ }^{2}$ Regions. The Regioni Italiane are autonomous territorial entities that have legislative and administrative powers.

${ }^{3}$ For further information, please refer to [13].

${ }^{4}$ In the following text we will leave unchanged the original terms, in particular those that currently define the structure of the Italian Education and Training System. In the notes we will try to indicate the comparable terms in use in the United States Education and Training System or, alternatively, the literal translation.
} 
- the description of the Italian Educational System in 2013, presented by the Ministry of Education, University and Research in the series The Notebooks of Eurydice, which refer to a network that provides information on and analyzes European Education Systems and Policies;

- the Document on Economic and Financial Affairs of 2014, which contains the National Reform Program where they are considered all the actions of the Government in Education, Training and Employment;

- the Annual Report on the Implementation of the Strategic Framework for European Cooperation in Education and Training (ET 2020) of 2011, edited by the Ministry of Labor and Social Policy, contained in a special issue of Vocational training and guidance;

- the Report on the State of the University and Research System of 2013 published by the National Agency for the Evaluation of the system of University and Research.

\section{The Role of the National State}

In Italy, the State has sole jurisdiction over the definition of general rules in the field of Education.

The Ministero dell'Istruzione, dell'Università e della Ricerca $^{5}$ (MIUR), is responsible for the administration of the Education System. The MIUR is organized into three Departments:

- the Department of Education carries out functions relating to Education Systems and general school organization, the definition of learning objectives and the legal, economic and social security position of school staff;

- the Department for Programming and Managing Human, Financial and Instrumental Resources performs functions related to financial policies, purchases, human resources management in the school administration field, management of information systems;

- the Department of University, Alta Formazione Artistica, Musicale e Coreutica (AFAM) $)^{6}$ and Research performs specific functions related to the Istruzione Superiore ${ }^{7}$ (including guidance and coordination), the general regulation and funding of Universities; the monitoring and evaluation of University and AFAM; the status of University and AFAM student; the implementation of European Union and international rules; policy, planning and coordination of Research at a national, international and European level [12] [9].

The MIUR operates on a decentralized basis through the Uffici Scolastici Regionali (USR) ${ }^{8}$ and the Uffici Scolastici Provinciali (USP).

\footnotetext{
${ }^{5}$ Ministry of Education, University and Research.

6 "Higher Education in Art, Music and Choreutics.

${ }^{7}$ Post-Secondary Education.

${ }^{8}$ Regional School Offices. The Uffici Scolastici Regionali (USR), established in 2000, are present in 18 Capoluoghi di Regione (a separate discipline exists in the Regioni Valle d'Aosta and Trentino-Alto Adige).
}

The Regional School Offices monitor compliance with the general rules on Education and the essential levels of performance, the implementation of School regulations, the levels of effectiveness of Educational Action and the compliance with the defined standards. Normally they are divided by function and they are present on the territory with offices at the provincial level that have no operational autonomy [9].

The Provincial Offices perform functions of assistance, advice and support to schools for administrative and accounting procedures, for the design and innovation of the Educational Offer and are engaged in monitoring school construction and safety of buildings. They take care of the state of integration of immigrant children and of the differently abled, the promotion and encouragement of student participation and, in collaboration with the Comuni ${ }^{9}$, they verify compliance with Compulsory Education [9].

The Ministero del Lavoro e delle Politiche Sociali ${ }^{10}$ (MDLDPS) defines and guarantees the essential levels of performance relating to the system of the Formazione Professionale $^{11}$ [9]. It is divided into 10 Directorates-General, including the Directorate that deals with active policies and services for Employment and Training [5].

The Ministry of Education, University and Research and the Ministry of Labor and Social Policy, define the essential levels of performance relating, respectively, to the system of the Istruzione $^{12}$ and to the system of the Formazione Professionale.

\section{The Role of the Regioni}

The Regioni provide:

- concurrent legislative competence in the field of Istruzione;

- exclusive competence in the field of Istruzione $e$ Formazione Professionale ${ }^{13}$, both for programming and for the management and delivery of the offer through Accredited Agencies.

Regions exercise these competences in close collaboration with the Ministries, through the State/Regions Joint Conference [9].

The Permanent Conference for relations among the State, Regions and Autonomous Provinces of Trento and Bolzano is the pivotal forum for political negotiations between the central government and the Sistema delle Autonomie Locali ${ }^{14}$. The agreement, reached unanimously, is the means by which the Government, Regions and Autonomous Provinces coordinate the exercise of their respective competences and the performance of activities of common interest, implementing

\footnotetext{
${ }^{9}$ Municipalities.

${ }^{10}$ Ministry of Labor and Social Policy.

${ }^{11}$ (Vocational) Training.

12 Education.

${ }^{13}$ Vocational Education and Training.

${ }^{14}$ Local Self-Government. For further information on the Local Self-Government please refer

http://en.wikipedia.org/wiki/European_Charter_of_Local_Self-Government
} 
the principle of loyal cooperation [12].

\section{The Scuola Dell'Infanzia}

\subsection{Structure}

They provide Education and care to early childhood:

- the Asili Nido (children between the ages of 0 and 3 years old), which are not part of the Educational System and do not fall under the MIUR jurisdiction, but are managed by Municipalities within the general criteria established at the Regional level;

- the Scuole dell'Infanzia ${ }^{15}$ (children between the ages of 3 and 6 years old), which are part of the Educational System and are MIUR responsibility, but can also be managed locally by Municipalities and even by private parties.

The Educazione Pre-Primaria ${ }^{16}$ is not compulsory.

\subsection{The Indicazioni Nazionali Per Il Curricolo}

The Indicazioni Nazionali per il Curricolo ${ }^{17}$ form the framework for curricula designing entrusted to schools. They are an open text that the professional community is called to assume and to contextualize, developing specific choices related to content, methods, organization and evaluation, within the Educational Goals set out by the National Education System [2].

The Guidelines assign to School the overall purpose of harmonious and integral development of the person, within the principles of the Italian Constitution and the European cultural tradition, in the promotion of knowledge and with respect and appreciation for the individual differences, with the active involvement of students and families. They take as a reference horizon to work towards the Framework of Key Competences for Lifelong Learning [11].

In particular, the Scuola dell'Infanzia aims to promote in children the development of identity, autonomy and competence and to introduce them to citizenship. There are five fields of experience, each of which offers a set of objects, situations, images and languages, referring to the symbolic systems of our culture, able to evoke, stimulate and accompany a progressively safer learning: the Self And the Other; Body and Movement; Images, Sounds, Colors; Speeches and Words; Knowledge of the World.

Targets for the development of competences are set for each field of experience. Those targets are unavoidable references for teachers, indicate Cultural and Educational tracks to go and help to finalize the Educational Activity to the integral development of the student.

Starting from the school year 2010/2011 is in force the discipline Citizenship and Constitution, the contents of which are developed through learning paths designed by each school.

\footnotetext{
${ }^{15}$ Pre-Kindergarten.

${ }^{16}$ Pre-Primary Education.

17 National Guidelines for the Curriculum. The Indicazioni Nazionali per il Curricolo are applied starting from the school year 2012/2013 [9].
}

\section{The Primo Ciclo di Istruzione}

\subsection{Structure}

The Primo Ciclo di Istruzione ${ }^{18}$ is divided into two segments:

- the Scuola Primaria ${ }^{19}$ [12] or Istruzione Primaria [9];

- the Scuola Secondaria di Primo Grado ${ }^{20}$ [12] or Istruzione Secondaria Inferiore Generale [9].

At the Scuola Primaria you access from 6 years of age, it has a total duration of five years and it is divided into three teaching periods that last, respectively, one year, two years and two years.

At the Scuola Secondaria di Primo Grado you access from 11 years of age, it has a total duration of three years and it is divided into teaching periods, respectively, of two years and one year.

The Primo Ciclo di Istruzione is compulsory.

Central and Peripheral State Administrations and Regional, Provincial and Local Administrations ensure the establishment and operation of Schools throughout the country.

The Istruzione Secondaria Inferiore is offered by the Scuole Secondarie di Primo Grado, both State Schools (National Schools) and Scuole Paritarie ${ }^{21}$, present throughout the national territory [9].

The Scuole Paritarie are non-state Educational Institutions (including those of the Enti Locali ${ }^{22}$ ) that, starting from the Scuola dell'Infanzia, "correspond to the laws of General Education, are consistent with the Educational demand of families and are characterized by the requirements of quality and effectiveness [...]" [4]. They are recognized by the MIUR, that ensures the original possession and retention of requirements ${ }^{23}$.

Education requirement may also be fulfilled in the mode of home schooling or at a private school.

To ensure a process of continuous learning within the same Education Cycle there is the possibility to create, under the direction of a single School Administrator, the Scuole Comprensive, consisting of Scuole Primarie, Scuole Secondarie and even Scuole dell'Infanzia.

\subsection{The Indicazioni Nazionali Per Il Curricolo}

On the basis of the National Guidelines for the curriculum, the specific purpose of the Scuola Primaria and Scuola Secondaria di Primo Grado is the acquisition of the fundamental knowledge and abilities needed to develop Basic Cultural Competences.

In particular, in the Scuola Secondaria di Primo Grado is achieved the access to Disciplines as points of view on reality

\footnotetext{
${ }^{18}$ First Cycle of Education.

${ }^{19}$ Elementary School.

${ }^{20}$ Middle School (Junior High School).

${ }^{21}$ Charter Schools.

${ }^{22}$ Local Authorities.

23 Law No. 62 of 10 March 2000. Online available from: http://www.lescuoleparitarie.com/cosa_e_un_istituto_paritario.html. For further information, please refer to [2].
} 
and as a mode of knowledge, interpretation and representation of the world.

The disciplines considered in the Scuola Primaria are: Italian, English, History, Geography, Mathematics, Science, Technology and Computer Science, Music, Art and Image, Physical Education, Technology.

The disciplines considered in the Scuola Secondaria di Primo Grado are: Italian, English and Second Foreign Language, History, Geography, Mathematics, Science, Music, Art and Image, Physical Education, Technology.

These are supplemented by the discipline Citizenship and Constitution, the contents of which are developed through learning paths designed by each school.

For each discipline are established:

- the goals for the development of Competences to be achieved at the end of the Scuola Primaria and Scuola Secondaria di Primo Grado;

- the Learning Objectives, which identify the fields of knowledge and abilities considered essential in order to achieve the Goals for the development of Competences.

\subsection{The Final Examination of the Primo Ciclo}

The State examination concluding the Primo Ciclo di Istruzione takes place at the end of the third year of the Scuola Secondaria di Primo Grado.

The Examination includes:

- a national written test developed by the INVALSI ${ }^{24}$;

- four written tests developed by the Examination Board on Italian, Mathematics and Elements of Science and Technology, the two European Languages studied;

- an oral discussion on all subjects of the last year.

The Examination Board consists of classes' teachers and it is chaired by an external member. It is divided into Subcommittees that assess the four written tests.

The final grade is calculated by averaging the grades obtained in all written tests, including the test of the INVALSI, in the multidisciplinary oral exam and the judgment of suitability needed for admission to the Examination. The Examination is successfully passed if the overall rating is equal to or greater than $6 / 10$.

The final grade obtained is illustrated by an analytical Certification of Competences and of the overall level of maturity attained by the pupil.

To access the Secondo Ciclo di Istruzione is necessary to pass the State Examination concluding the primo Primo Ciclo di Istruzione and achieve the related Diploma.

\section{The Secondo Ciclo di Istruzione}

\subsection{Structure}

The Secondo Ciclo di Istruzione ${ }^{25}$ includes courses of

\footnotetext{
${ }^{24}$ Istituto Nazionale per la Valutazione del Sistema Educativo di Istruzione e di Formazione (National Institute for the Evaluation of the Educational System of Education and Training). For further information, please refer to: http://www.invalsi.it/invalsi/index.php.

${ }^{25}$ Second Cycle of Education.
}

different duration, which are divided into two sectors:

- the Istruzione Secondaria di Secondo Grado ${ }^{26}$ [12] or Istruzione Superiore Generale [9] under State Jurisdiction;

- the Istruzione e Formazione Professionale ${ }^{27}$ of Regional Competence [12] [9].

The completion of Compulsory Education ${ }^{28}$ is carried out with the attendance of the first two years of the Educational Paths of the Secondo Ciclo.

The right-duty to Education and Training ${ }^{29}$ can be fulfilled: in the system of the Istruzione Secondaria di Secondo Grado; in the system of the Istruzione e Formazione Professionale; in the Apprendistato per la Qualifica e il Diploma Professionale $^{30}$; in Parental Education.

Knowledge and competences that all students should have acquired by the end of Compulsory Education (beyond the specific programs for the different paths of Istruzione Secondaria Superiore) refer to:

- the cultural axes of Languages, Mathematical, Scientific and Technological, Socio-Historical;

- the key competences [11] of Learning to Learn; Plan; Communicate; Collaborate and Participate; Act Independently and Responsibly; Solve Problems; Identify Connections and Relationships; Acquiring and Interpreting Information ${ }^{31}$.

\subsection{The State Istruzione Secondaria di Secondo Grado}

To the Istruzione Secondaria di Secondo Grado you access following the passing of the State examination placed at the end of the Primo Ciclo di Istruzione. It has a total duration of five years and is divided into teaching periods, respectively, of two years, two years and one year.

The Istruzione Secondaria di Secondo Grado consists of three types of offer:

- Istruzione Liceale ${ }^{32}$ (paths: Artistic, Classical, Linguistic, Scientific, of Human Sciences, Musical,

\footnotetext{
${ }^{26}$ (General) High School.

${ }^{27}$ Regional Vocational Education and Training.

${ }^{28}$ Education, imparted for at least ten years, is compulsory and is intended to allow the achievement of a Titolo di Studio di Scuola Secondaria Superiore or a Qualifica Professionale of at least three years of duration, before the age of eighteen (Law No. 296 of 27 December 2006, Article 1, paragraph 622). For further information, please refer

http://www.normattiva.it/uri-res/N2Ls?urn:nir:stato:legge:2006-12-27;296.

${ }^{29}$ It is assured everyone the right to Education and Training for at least twelve years, anyway, until the achievement of a Qualification by the age of eighteen; the actualization of this right is realized in the Sistema di Istruzione and in the Sistema di Istruzione e Formazione Professionale [...]. The fruition of Education and Training is a duty legislatively sanctioned (Law No. 53 of 2003, Article 2, paragraph 1, letter c). For further information, please refer to: http://www.camera.it/parlam/leggi/030531.htm.

${ }^{30}$ Young people who have reached 15 years of age can fulfill their obligation even through the conclusion of a contract of Apprendistato per la Qualifica e il Diploma Professionale (Law Decree No. 167 of 14 September 2011, Article 3, paragraph 1). For further information, please refer to: http://www.normattiva.it/uri-res/N2Ls?urn:nir:stato:decreto.legislativo:2011-09-1 $4 ; 167$. On the Apprendistato please see Paragraph 8 of this text.

${ }^{31}$ For further information on the use of cultural axes and key competences in the Italian System of Education and Training, please refer to [15].

${ }^{32}$ High School.
} 
Choreutic);

- Istruzione Tecnica 33 (sectors: Economic, Technological);

- Istruzione Professionale ${ }^{34}$ (sectors: of Services, Industry and Commerce) [12].

The National Guidelines for the Licei and for the Istituti Tecnici e Professionali establish the specific Learning Objectives for each Discipline (essential knowledge and abilities for the development of Competences). They include The Student Educational, Cultural and Professional Profile where is established what a student should know and be able to do at the end of the Liceo or the Istituto tecnico-professionale [9].

It is currently in force the discipline Citizenship and Constitution, the contents of which are developed through learning paths designed by each school.

Teaching a non-language discipline in a foreign language is compulsory in the fifth year of all the Lice $^{35}$.

At the conclusion of the courses of the Scuola Secondaria di Secondo Grado the student takes a State Examination.

The Examination is for testing:

- the fundamental knowledge and competences acquired in the last year of the course in relation to the general and specific objectives specific to each curriculum;

- the general cultural basics;

- the critical ability of the candidate.

The Examination consists of three written tests and an oral exam.

The first written test verifies the mastery of the Italian language or the language in which teaching takes place and the expressive, logical-linguistic and critical capabilities of the candidate.

The second written test (which can also be graphic or written-graphic) relates to one of the disciplines that distinguish the Course of Study;

The third written test is expression of the teaching methodology and organization of the single school and is closely related to the Piano dell'Offerta Formativa ${ }^{36}$ (POF) used. It is a test of multidisciplinary nature, which covers the disciplines of the final year of the course and consists of the concise treatment of topics, in the reply to single or multiple questions or in solving problems or practical and professional cases or in the development of projects. Normally, this test is structured in such a way as to allow also to verify the knowledge of a foreign language.

The texts of the first and the second written test, selected by the Minister, are sent by the MIUR; the text of the third written test is developed by the Examination Board with preset modes.

\footnotetext{
${ }^{33}$ Technical (High School) Education.

${ }^{34}$ Professional (High School) Education.

${ }^{35}$ Content and Language Integrated Learning (CLIL).

${ }^{36}$ The Piano dell'Offerta Formativa is the identity card of the school: it describes the distinctive lines of the Institute, the Cultural-Pedagogical inspiration that moves it, the Curricular, Extra-Curricular, Didactic and Organizational Design of its Activities. For further information, please refer to: http://archivio.pubblica.istruzione.it/argomenti/autonomia/pof/default.shtml.
}

The Examination Board consists of no more than six members, of which fifty percent internal members and the remaining fifty percent from outside the Institute, plus the President, external member. The external commissioners are appointed from among the teachers of the Istituti Statali di Istruzione Secondaria Superiore ${ }^{37}$.

At end of the State Examination, to each candidate is assigned a final mark in hundredth, which is the sum of the points attributed by the Examination Board in the written tests and in the oral exam and the points for the School Credit attained by each candidate. The minimum score to pass the exam is $60 / 100$.

Those who pass the final exam will receive a Diploma and a Certificate illustrating in detail the student's career, drawn up in four European languages ${ }^{38}$.

\subsection{The Regional Istruzione e Formazione Professionale (IFP)}

Upon completion of the Primo Ciclo di Istruzione you can access to the Istruzione e Formazione Professionale ${ }^{39}$. To register to the first year it is required to be under the age of 15 . To register to the second and subsequent years, young people who come from other paths must be below the age of 18 .

The paths of Istruzione e Formazione Professionale can:

- have a duration of three years and issue the Attestato di Qualifica Professionale di Operatore professionale ${ }^{40}$;

- have a duration of four years and issue the Diploma Professionale di Tecnico ${ }^{41}$.

The certification is aimed at the recognition of Qualifications and Diplomas that allow the entry or re-entry into the System of Education and Training. Certified competences form Training Credit [9].

The paths of Istruzione e Formazione Professionale can be provided by:

- Vocational Training Agencies accredited by Regions on the basis of criteria shared with the State;

- Institutions of the State Scuola Secondaria di Secondo Grado that follow the guidelines issued by Regions.

Within the possibilities offered by the current legislation the majority of Regions opted for a supplementary subsidiary offer, which allows students enrolled in the state five-year courses to get in the third year the Qualifications of Regional Vocational Training [9].

For the three-year and four-year Vocational Education and Training paths of regional competence, there are no study programs of a national character arranged according to disciplines.

The Agencies prepare an Educational Project, based on the analysis of tasks and competences that characterize the Professional Figure target of the action. It is widespread the planning of actions structured in modules ascribable to:

\footnotetext{
${ }^{37}$ For further information, please refer to [9].

${ }^{38}$ For further information, please refer to[9].

${ }^{39}$ Please see note 27.

${ }^{40}$ Certificate of Professional Qualification of Professional Operator.

${ }^{41}$ Vocational Diploma.
} 
- Basic and Transversal Competences, with particular reference to the Key Competences for Citizenship [11] in order to elaborate the Curriculum for the first two years of compulsory education;

- Technical and Professional Competences, with particular reference to the technical and professional standards expected for the Professional Figures exiting the three-year and four-year paths ${ }^{42}$.

Examinations are generally of three types: theoretical test or written test; practical test in laboratories or with machines or simulations of solving a problem through a case study; oral exam.

The regional landscape is still differentiated with respect to: the preparation of tests, the overall judgment of suitability that leads to the acquisition of the Qualification Certificate, the composition of the Examination Boards ${ }^{43}$.

With regard to the possibility to access further Education and Training paths:

- the acquisition of the Qualification at the end of the third year makes it possible to subscribe to the fourth year of Specialization, only offered by some Training Agencies in some Regions;

- only for some Professional Figures, the acquisition of the Qualification at the end of the third year makes it possible to subscribe to the third or fourth year of the Scuole Secondarie Superiori (especially Istituti tecnici e professionali) with the corresponding Qualification.

In addition, with the Professional Qualification you can enroll in the Percorsi di Formazione Professionale Post Qualifica o Post Diploma ${ }^{44}$ or be hired with a Contratto di Apprendistato Professionalizzante ${ }^{45}$ (for young people over the age of 18).

Young people in possession of a Diploma Professionale di Tecnico awarded on completion of four-year Vocational Education and Training Paths can go to University, AFAM and Istituti Tecnici Superiori ${ }^{46}$ (ITS), after attending a special annual course at the expense of Regions, realized in integration between Educational Institutions and Accredited Agencies of the Territory.

\section{The Istruzione Superiore}

\subsection{Structure}

The courses of the Istruzione Superiore ${ }^{47}$ are provided by:

- the University System (Università; Scuole Superiori per Mediatori Linguistici; Istituti di Specializzazione in Psicoterapia);

- the System of the Alta Formazione Artistica e Musicale ${ }^{48}$

\footnotetext{
42 For further information on the Professional Figures, please refer to: http://archivio.pubblica.istruzione.it/dg_post_secondaria/avviso180112.shtml.

${ }^{43}$ For further information, please refer to [9].

${ }^{44}$ Post Diploma or Post-Qualification Vocational Training Paths.

45 Professional Apprenticeship Contract. On the Apprendistato please see paragraph 8 of this text.

${ }^{46}$ Higher Technical Institutes.

${ }^{47}$ Higher Education.

${ }^{48}$ Higher Education in Art and Music. Please see note 6.
}

(Accademie delle Belle Arti; Istituti Superiori per le Industrie Artistiche; Accademia Nazionale di Arte Drammatica Silvio d'Amico; Conservatori di Musica; Accademia Nazionale della Danza);

- the System of the Istruzione e Formazione Tecnica Superiore $^{49}$ (Istituti Tecnici Superiori, ITS; Percorsi di Istruzione e Formazione Tecnica Superiore, IFTS)

- the Istituti a Fini Speciali ${ }^{50}$ (Scuola Nazionale di Cinema; Istituto Centrale del Restauro; Scuola di Restauro del Mosaico; Scuola dell'Opificio delle Pietre Dure; Scuole di Archivistica Paleografia e Diplomatica; Accademie Militari; Istituti Superiori di Scienze Religiose; Istituto Centrale per la Patologia del Libro Alfonso Gallo; Fondazione per la Conservazione dei Beni Librari).

According to the Agreements established referring to the European Qualifications Framework for Lifelong Learning ${ }^{51}$ (EQF, 2008) and the Framework of Qualifications for the European Higher Education Area ${ }^{52}$ (EHEA, 2005) and their recognized equivalence ${ }^{53}$, Italian Istruzione Superiore is structured in the following way:

- EQF Level 6/EHEA First Cycle: courses for the achievement of the University Laurea; courses for the achievement of the AFAM Diploma di Primo Livello.

- EQF Level 7/EHEA Second Cycle: courses for the achievement the University Laurea Magistrale; courses for the achievement of the University Master di Primo Livello; courses for the achievement of the AFAM Diploma di Secondo Livello; courses for the achievement of the AFAM Diploma Accademico di Specializzazione (I); courses for the achievement of the AFAM Diploma di Perfezionamento or Master (I);

- EQF Level 8/EHEA Third Cycle: courses for the achievement of the University Dottorato di Ricerca; courses for the achievement of the University Diploma di Specializzazione; courses for the achievement of the University Master di Secondo Livello; courses for the achievement of the University Diploma di Perfezionamento; courses for the achievement of the AFAM Diploma Accademico di Formazione alla Ricerca; courses for the achievement of the AFAM Diploma di Specializzazione (II); courses for the achievement of the AFAM Diploma di Perfezionamento or Master (II); Equivalent Qualifications (Diploma of

\footnotetext{
${ }^{49}$ Higher Technical Education and Training.

${ }^{50}$ Istituti superiori (Higher Education Institutions) that do not grant Qualifications equivalent to those of the First, Second and Third Cycle of Higher Education (as defined under the Agreement A framework of Qualifications in the European Higher Education Area of May 2005). For further information, please refer to: http://www.ehea.info/article-details.aspx?ArticleId=73).

51 For further information on the $\mathrm{EQF}$, please refer to: http://eur-lex.europa.eu/LexUriServ/LexUriServ.do?uri=OJ:C:2008:111:0001:000 7:EN:PDF.

52 For further information on the EHEA, please refer to: http://www.ehea.info/Uploads/Documents/QF-EHEA-May2005.pdf.

${ }^{53}$ The equivalence of the two Framework was explicitly recognized in 2007 by the Ministers responsible for Higher Education who met in London and it was made explicit in the EQF Recommendation [9].
} 
Psychotherapist) [12].

With relation to the EQF Framework the system of Vocational Education and Training is structured as follows:

- EQF Level 3: courses for the achievement of the Attestato di Qualifica di Operatore Professionale;

- EQF Level 4: courses for the achievement of the Diploma Professionale di Tecnico; courses for the achievement of the Certificato di Specializzazione Tecnica Superiore;

- EQF Level 5: courses for the achievement of the Diploma di Tecnico Superiore [12] ${ }^{54}$.

\subsection{University Education}

The Diploma di Istruzione Secondaria Superiore provides access to the University Laurea ${ }^{55}$ courses. University Laurea course in Medicine and Surgery, Veterinary Medicine, Architecture and all University Laurea courses whose Ordinamento Didattico ${ }^{56}$ provides for the obligation of the Tirocinio $^{57}$ have limited access.

Universities establish Courses of Study organized in three cycles:

- First Cycle provides the University Laurea courses lasting three years, the acquisition of 180 Crediti Formativi Universitari ${ }^{58}$ (CFU) and the conferment of the Qualification of Dottore;

- Second Cycle provides the University Laurea Magistrale $^{59}$ courses lasting two years, the acquisition of 120 CFUs and the conferment of the Qualification of Dottore Magistrale;

- Third Cycle is dedicated to the Corsi di Specializzazione and the Dottorato di Ricerca. The Dottorato di Ricerca, lasting at list three years, confers the Qualification of Dottore di Ricerca.

General criteria for the structure of University Studies and the type of Qualifications awarded by Universities are defined at the central level.Courses are organized in the following areas of study: Health, Scientific, Social, Humanistic [9].The MIUR has established a number of Classi di Laurea (43) and Classi di Laurea Magistrale (94), which merge University Courses that share qualifying Learning Objectives, essential Learning Activities and the minimum number of Credits required $^{60}$.

\footnotetext{
${ }^{54}$ The listed Qualifications will be illustrated later in the text in the pertaining sections.

55 Bachelor's Degree.

${ }^{56}$ Didactic structure. On the Ordinamenti Didattici, please see the final part of the paragraph.

${ }^{57}$ Please see note 66

${ }^{58}$ On the Crediti Formativi Universitari please see the pertaining paragraph of this text.

${ }^{59}$ Master's Degree. Medicine and Surgery; Veterinary Medicine; Dentistry and Dental Prostheses; Pharmacy; Architecture; Law; are Corsi di Laurea Specialistica/Magistrale a Ciclo Unico: the admission is subject to a selection test and studies are structured over 5 years and $300 \mathrm{CFU}$ (6 years and $360 \mathrm{CFU}$ for Medicine and Surgery) [12].
}

60 For further information on the Classi, please refer to: http://www.miur.it/0002Univer/0021Offert/0093Classi/index_cf2.htm.
According to the legislation, each Class must provide for:

- Learning Activities related to Basic Education;

- Learning Activities in one or more Domains typical of the Class;

- Learning Activities in one or more domains Related or Additional to those that characterize the Field of Study;

- Learning Activities autonomously chosen by students;

- Learning Activities related to the preparation of the Final Examination for the achievement of the Qualification and the verification of knowledge of the foreign language;

- Other Learning Activities aimed at improving Linguistic Knowledge, as well as Computer Skills, Relational Skills or Skills that may be useful for entering the world of Work, including, in particular, Tirocini Formativi and Tirocini di Orientamento ${ }^{61}$.

At central level is established the minimum number of credits that Universities, in their Regolamento Didattico, must reserve to each Learning Activity and each Disciplinary Domain. The minimum number of credits determined at Ministerial level on the total credits required for obtaining the Qualification is $66 \%$.

Within their autonomy, each University issues the Regolamenti Didattici and approve the Ordinamenti Didattici.

The Regolamenti Didattici determine:

- the denomination and the learning objectives of the Courses of Study, the general framework of learning activities to be included in the curricula, the credits assigned to each learning activity, the characteristics of the Final Examination for obtaining the Qualification;

- the aspects of the organization of the teaching activity common to the Courses of Study;

- the procedures for the assignment of the annual teaching tasks to Professors and Researchers;

- the procedures for the execution of Examinations;

- the Evaluation modalities of student's advancement, in accordance with the criteria established at central level;

- the Evaluation modalities of students' initial knowledge and the organization of learning activities preparatory to the Evaluation of initial knowledge;

- Quality Evaluation of the activities carried out;

- The Ordinamenti Didattici discipline:

- the list of Insegnamenti62;

- the specific Learning Objectives and related Credits;

- the Piani di Studio63 offered to students and the rules for the submission of the individuals Piani di Studio;

- Regulations regarding the possible Compulsory Attendance.

\subsubsection{The Crediti Formativi Universitari (CFU)}

As previously mentioned, the recognition of students' workload in the University environment is based on a System

\footnotetext{
${ }^{61}$ Please see note 66.

${ }^{62}$ Different Subjects that constitute each Course of Study.

${ }^{63}$ Curriculum. The set of learning activities considered for the achievement of the Qualification.
} 
of Credits.

The Crediti Formativi Universitari ${ }^{64}$ indicate the amount of academic work, including individual study, required of a student engaged in the learning activities provided by the Ordinamenti Didattici of the Courses of Study.

One credit corresponds to a minimum of 25 hours of work per student.

The average amount of academic work done in one year for a student engaged in full-time University Studies is conventionally fixed at 60 credits.

The total or partial recognition of credits acquired for the purpose of continuation of studies is the responsibility of the Educational Institution that accepts the student.

The Regolamenti Didattici can provide forms of periodic verification of credits and the minimum number of credits to be achieved by the student at predetermined times.

According to predetermined criteria, Universities may recognize as CFUs, certified competences and professional skills in accordance with the current legislation and other abilities and competences gained in learning activities of post-secondary level whose design and implementation the University has combine to bring about.

The Crediti Formativi Universitari correspond to the credits of the European Credit Transfer and Accumulation System (ECTS) ${ }^{65}$ [9].

In order to attend the Courses of Study of the following year, students must earn the required credits from their Piano di Studi for each academic year and pass the Examinations provided in the Piano.

The Regolamenti Didattici of individual Universities determine the procedures and criteria to be followed in the event of a request to switch from one Course of Study to another of the same or another University. However that may be, they have to ensure the recognition of the greatest possible number of Credits accumulated by the student. In the case of transfer among Corsi di Laurea of the same Classe, the recognition of credits can not be less than $50 \%$ [9].

\subsubsection{The Stage or Tirocinio Universitario}

The Stage or Tirocinio ${ }^{66}$ can be done during University Studies or after their conclusion, in combination with the State Examination, as provided by law for the access to Regulated Professions ${ }^{67}$ (Ordini Professionali and the respective Albi Professionali).

The Tirocinio or Stage can be:

\footnotetext{
${ }^{64}$ University (Learning) Credits.

65 For further information on the ECTS, please refer to: http://ec.europa.eu/education/tools/ects_en.htm.

${ }^{66}$ Traineeship. The term Tirocinio (from Latin tirònes or Greek tèrèo), in Italian often replaced with the term Stage (from the French Stage, pronounced /'sta3/) indicates an experience of very variable duration in a Public or Private Institution for the primary purpose of Learning and Training. For further information, please refer to: http://it.wikipedia.org/wiki/Tirocinio. For information on the current regulation of the Tirocini Formativi please refer to: http://www.cliclavoro.gov.it/NormeContratti/Contratti/Pagine/Contratto-di-stage.a spx.

${ }^{67}$ Please see also note 74 and note 105 .
}

- provided in the Ordinamento Didattico of a Course,

- provided through International Programs,

- take place in a free form based on a Business Offer to students and teachers.

The Stage must:

- be carried out within Guidance and Learning Projects,

- be carried out on the basis of Agreements among the parties involved,

- predict the presence of a Tutor who has the Didactic and Organization responsibility of the activities.

- make the Credits recognition of performed activities possible [9].

\subsubsection{University Evaluation and Certification}

Procedures and methods for evaluating students are delegated to the University Regolamenti Didattici.

The current legislation at the national level requires that the vote:

- is expressed in thirtieths for each exam (scale 0-30, with 18 as the minimum grade)

- is expressed in hundredth for the final examination (scale 0-110, with 66 as the minimum grade).

At the maximum value of each of the two evaluative scales it can be added the Lode 68 as a distinguishing note of merit (30 e/con Lode; 110 e/con Lode).

To achieve a First Cycle Qualification the student must:

- have passed all the exams required by the Piano di Studi and have acquired a total of 180 credits, corresponding to three years of study in First-Cycle Programs;

- undergo a Final Individual Test in front of an Examination Board.

To achieve a Second Cycle Qualification, the student in possession of First Cycle Qualification, must:

- have passed all the exams required by the Piano di Studi and have acquired a total of 120 credits (300-360 in the case of Single-Cycle Programs ${ }^{69}$ ), corresponding to two years of study;

- undergo a Final Test in front of an Examination Board.

The test consists in the presentation of a Tesi elaborated in an original manner by the student under the guidance of a Relatore $^{70}$.

Qualifications of Master di Primo Livello and Master di Secondo Livello do not have national Ordinamenti Didattici and are issued under the autonomous responsibility of the single University. Hence, they do not allow access to Third Cycle Courses [9].

The University Ordinamenti Didattici govern the modalities and procedures for issuing the corresponding Certification and the Supplemento al Diploma ${ }^{71}$.

\footnotetext{
${ }^{68}$ Laude, Honour.

${ }^{69}$ Please see note 59

${ }^{70}$ Supervisor.

71 The Supplemento al Diploma provides a description of the nature, level, context, content and status of the studies carried out and completed by the student in a standardized format in 8 points, developed by the European Commission, the Council of Europe and UNESCO (United Nations Educational Cultural and Scientific Organization). For further information, please refer to: http://hubmiur.pubblica.istruzione.it/web/universita/diploma-supplement.
} 
On the basis of specific agreements, some Institutions may issue Qualifications together with other Italian and foreign Institutions (Titoli Congiunti $^{72}$ ). All must be on the same level and authorized to issue Qualifications recognized within the Italian Legislation, according to the rules of the European and International Law.

The Qualifications issued have the value of Academic Qualifications and do not qualify for Regulated Professions. They give access to State Examinations for the Abilitazione Professionale $^{73}$, the passing of which allows the registration in the Albo Professionale ${ }^{74}$.

\subsubsection{The University Dottorato di Ricerca}

The Corsi di Dottorato di Ricerca ${ }^{75}$ are aimed at providing the competences necessary for carrying out Highly Qualified Research Activity.

The Corsi di Dottorato must be accredited by the MIUR with the assent of the National Agency for the Evaluation of Universities and Research Institutes (ANVUR) ${ }^{76}$.

The MIUR establishes the procedures for the accreditation of the $\mathrm{Sedi}^{77}$ and the Courses and the criteria and parameters for their institution. Based on these criteria, the Accredited Bodies regulate, with their own rules, the procedures of access and attainment of the Qualification; the Learning Objectives and the related Program of Study; the duration, the contribution to the enrolment, the attendance; the number, the mode of contribution and the amount of the Borse di Studio ${ }^{78}$.

The Corsi are instituted by:

- Istituti di Istruzione Universitari a Ordinamento Speciale ${ }^{79}$ and qualified Istituzioni Italiane di Formazione e Ricerca Avanzate ${ }^{80}$;

- consortia among Universities or among Universities and Highly Qualified Research Institutions in the public and private sphere.

In any case the Academic Qualification is awarded by Universities.

Those who are in possession of a Laurea Magistrale can enter in the Dottorato di Ricerca through a Concorso Pubblico ${ }^{81}$.

Each University sets its own rules for the evaluation and supervision of Doctoral Students, in addition to the evaluation tests of the activities carried out. Each course has its own Collegio Docenti ${ }^{82}$ and a Coordinator. Students may be followed by a Tutor according to the rules and procedures established by the University.

\footnotetext{
72 Joint Qualifications.

${ }^{73}$ Professional License.

${ }^{74}$ Professional Register. For further information on the Albi Professionali please refer to: http://www.gazzettadellavoro.com/albo-professionale/26244/.

${ }^{75}$ Research Doctorate or Doctor of Philosophy (Ph.D) Courses.

76 For further information on the ANVUR please refer to: http://www.anvur.org/index.php?lang=it.

77 Campuses.

${ }^{78}$ Scholarships.

${ }^{79}$ University Education Institutes under Special Jurisdiction

${ }^{80}$ Italian Institutions for Advanced Education and Research.

${ }^{81}$ For further information on the Concorsi Pubblici please refer to: http://www.concorsipubblici.com/formazione/guida-concorsi-pubblici.html.

${ }^{82}$ Doctoral Board.
}

The course duration is a minimum of three years and provides for the development of a final Tesi di Ricerca ${ }^{83}$ and its Discussione ${ }^{84}$ [12].

The Tesi is evaluated by at least two Highly Qualified Professors who express a written analytical assessment on the Tesi and propose its admission to the Discussione Pubblica. Once admitted, the Tesi is presented to an Academic Board whose composition is defined in the University own Regolamenti [9].

On completion of the Corso di Dottorato di Ricerca is awarded the Academic Qualification of Dottore Di Ricerca (Dott. Ric.) or PhD.

\subsection{The Alta Formazione Artistica e Musicale (AFAM)}

The Institutions of the Alta Formazione Artistica $e$ Musicale (AFAM) offer a highly qualified professional Specialization in the following fields:

- Visual Arts with Specialization in Painting; Sculpture; Decoration; Set Design; and, more recently, Photography; Multimedia; New Technologies for Art; Film and Television Set Design; Conservation and Restoration of Works of Modern and Contemporary Art;

- Dramatic Art, with courses in Acting and Directing; in the field of Dance, with Courses in Classical and Contemporary Dance and the Course of Choreography;

- Music, with all the musical instruments, but also Jazz and Electronic Music;

- Design, with Product Design; Communication Design; Systems Design and Fashion Design [9].

The Qualification for the admission to AFAM Courses is the Diploma di Istruzione Secondaria Superiore.

First Level Academic Courses of Music Conservatories and of the Music Institutes Pareggiati ${ }^{85}$ and the National Dance Academy admit students without a Diploma di Istruzione Secondaria Superiore, if they have outstanding abilities and aptitudes. The Diploma is still necessary for the achievement of the final Academic Qualification.

The Regolamenti Didattici define the knowledge required for admission and determine the modes of verification.

The recognition of students' workload for the AFAM Courses refers to the Crediti Formativi Accademici (CFA), that follow rules of operation similar to those of the Crediti Formativi Universitari (CFU). Like the latter, CFA correspond to ECTS credits.

The AFAM Institutions establish Courses of Study organized in three cycles:

- First Cycle provides courses for the Diploma Accademico di Primo Livello, lasting three years with the acquisition of 180 Crediti Accademici (CFA);

- Second Cycle provides courses for the Diploma Accademico di Secondo Livello, lasting two years with the acquisition of $120 \mathrm{CFA}$; courses for the Diploma

\footnotetext{
${ }^{83}$ Doctoral Dissertation.

${ }^{84}$ Academic Defence.

${ }^{85}$ The Istituti Pareggiati are not state Institutes, but legally recognized by the State. On the Parità please see also the Scuole Paritarie in Paragraph 4.1 of this text.
} 
Accademico di Specializzazione (I), lasting two years with the acquisition of $120 \mathrm{CFA}$; Corsi di Perfezionamento or Masters, lasting one year with the acquisition of $60 \mathrm{CFA}$;

- Third Cycle provides courses for the Diploma Accademico di Formazione alla Ricerca; courses for the Diploma Accademico di Specializzazione (II), lasting for two years with the acquisition of 120 CFA; Corsi di Perfezionamento or Masters, lasting for one year with the acquisition of $60 \mathrm{CFA}$.

As in the case of University, they are established at a central level: the general criteria for the organization of the sector, the type of Qualifications awarded, the type of learning activities to be provided for each AFAM Course of Study. The minimum number of credits determined at Ministerial level on the total credits required for obtaining the Qualification is $60 \%$. For what concerns Evaluation, they remain valid the norms of national reference, respecting the autonomy of AFAM Institutions.

Similarly to the University System, AFAM Institutions refer to their own Regolamenti, Ordinamenti Didattici, Piani di Studio.

Each AFAM Course of Study can be structured internally into multiple Specializations and Orientations. Learning activities may be correlated to laboratory activities or artistic production.

To access the courses of the Second Cycle is required a First Cycle Qualification obtained in the AFAM System or in the University System. A procedure similar to that of University is provided to obtain a Second Cycle Qualification.

The Qualification for the Diploma di Perfezionamento or Master (I) does not have national Ordinamenti Didattici and is issued under the autonomous responsibility of the single Institution. Hence, it does not allow access to Third Cycle Courses [9].

Similarly to what happens in the University System, the AFAM System provides a Diploma Accademico di Formazione alla Ricerca in order to supply the competences necessary for planning and implementing Highly Qualified Research Activities [12].

A Second Cycle Qualification obtained at University (Laurea Magistrale) or at an AFAM Institution (Diploma Accademico di Secondo Livello) allows access to these Courses [9].

The matter is governed by the Regolamenti Didattici of the individual Institute [9].

\subsection{The Istruzione e Formazione Tecnica Superiore}

The Istruzione e Formazione Tecnica Superiore System ${ }^{86}$ provides:

- courses offered by the Istituti Tecnici Superiori (ITS);

- paths of Istruzione e Formazione Tecnica Superiore (IFTS).

Both types of courses are structured in Unità

\footnotetext{
${ }^{86}$ Higher Technical Education and Training System.
}

Capitalizzabili $^{87}$ (UC), designed as a set of Competences autonomously significant, consistent with the approach to Learning Outcomes.

\subsubsection{The Courses of the Istituti Tecnici Superiori}

The Istituti Tecnici Superiori ${ }^{88}$ (ITS) are established on the basis of the Piani Territoriali Regionali and take the form of the Fondazioni di Partecipazione ${ }^{89}$. The minimum organizational standard provides:

- an Istituto di Istruzione Secondaria di Secondo Grado Tecnico or Professionale;

- a Struttura Formativa Accreditata ${ }^{90}$ by the Regione for Higher Education;

- a company operating in the manufacturing sector to wich the Istituto Tecnico Superiore refers;

- a University Department or other body within the field of Scientific and Technological Research;

- an Ente Locale ${ }^{91}$.

They have access to the ITS courses young people and adults in possession of the Diploma di Istruzione Secondaria Superiore.

Courses have a duration of four semesters (1800 - 2000 hours).

The curricula develop:

- Basic General Competences, common to all technological areas (Linguistic; Communicative and Relational; Scientific and Technological; Legal and Economic; Organizational and Managerial);

- Technical and Professional Competences that are common to all the Figures of each Technological Area;

- Technical and Professional Competences related to Individual Professional Figures.

- The Courses provide lezioni teoriche, attività laboratoriali e tirocini in azienda ${ }^{92}$ even abroad, which must cover at least $30 \%$ of the total hours [9]. It is contemplated teaching some Disciplines in the English language.

The Fondazioni conduct an inbound check of Technical, Technological and English Language Basic Competences needed for successful participation in Learning Activities. Each Fondazione prepares the Assessment Tests of these Competences and defines the criteria to be adopted. A specific score is assigned to the vote of the Diploma di Istruzione Secondaria Superiore.

At the end of the path is awarded the Diploma di Tecnico Superiore, issued by the MIUR.

The Courses carried out under the Istituti Tecnici Superiori (ITS) refer to Figures pertaining to the following

\footnotetext{
${ }^{87}$ Capitalizable Units.

${ }^{88}$ Please see note 46.

${ }^{89}$ The Fondazione di Partecipazione is a legal institute under private law which is the new model of Italian management of initiatives in the field of cultural and non-profit organizations in general. For further information, please refer to: http://www.studiobellezza.it/non-profit/fondazione-di-partecipazione/119-che-cos e-la-fondazione-di-partecipazione.html.

${ }^{90}$ Accredited Agency.

${ }^{91}$ Local Authority.

${ }^{92}$ Lectures, Laboratory Activities, Traineeships in Companies.
} 
Technological Areas: Energy Efficiency; Sustainable Mobility; New Technologies for Life; New Technologies for the Made In Italy; Innovative Technologies for Cultural Goods and Activities and Tourism; Information and Communication Technologies.

For the purpose of issuing the Certification by the Istituto Tecnico or Professionale, courses conclude with a Final Assessment of the Competences acquired, conducted by Examination Boards composed in such a way as to ensure the presence of representatives from Schools, Universities, Vocational Training and Experts from the world of Work.

The Diplomi di Tecnico Superiore give access to the Concorsi Pubblici $i^{93}$ and to University with recognition of CFUs, as well as allowing access to the world of Work.

\subsubsection{The Paths of the Istruzione e Formazione Tecnica Superiore (IFTS)}

The Istruzione e Formazione Tecnica Superiore ${ }^{94}$ (IFTS) pathways are planned by the Regions, have nature of Specialization and are designed and managed by at least four Subjects, among them formally associated:

- an Istituto di Istruzione Secondaria,

- a Vocational Training Center,

- a University,

- a Company or other Public or Private Entities.

To IFTS pathways can access:

- young people and adults having a Diploma di Istruzione Secondaria Superiore;

- those who have completed the four-year paths earning a Diploma Professionale;

- those who have received admission to the fifth year of a Istruzione Liceale path;

- those who, without Diploma, have had an accreditation of acquired Competences in previous Education, Training and Work paths.

The IFTS Paths have a duration of two semesters for a maximum total of 800-1000 hours and are aimed at achieving a Certificato di Specializzazione Tecnica Superiore issued by the Regions.

The Economic Sectors of reference are: Agriculture; Industry and Crafts; Tourism; Transportation; Public Services and Private Services of Social Interest; Insurance and Financial Services [12].

\section{The Formazione Professionale Iniziale}

In response to professional needs that emerge from the territory, the Regions plan actions in Formazione Iniziale, issuing Bandi ${ }^{95}$ open to Accredited Agencies.

The Formazione Professionale Iniziale ${ }^{96}$ courses are aimed at young people having fulfilled the right-duty to Education and Training. To them generally have access

\footnotetext{
${ }^{93}$ Please see note 81 .

${ }^{94}$ Please see note 49.

${ }^{95}$ Request for Proposal.

${ }^{96}$ Initial Vocational Training.
}

young people inoccupati or disoccupati ${ }^{97}$ and sometimes those considered weak for the purposes of job placement.

These actions are aimed at users who have obtained:

- the Diploma di Scuola Secondaria di Secondo Grado;

- the Qualification of the three-year or four-year paths of the Istruzione e Formazione Professionale;

- the Laurea.

The actions can be:

- aimed at a Qualification or Specialization with respect to a Professional Figure of reference, typically lasting one year, amounting up to 400-600 hours, where is generally provided a Stage ${ }^{98}$ and the frequency of which is compulsory and free;

- aimed at the development of Competences, of short duration (20-40 hours) (Formazione Continua Regionale $^{99}$ ) [12].

In the first case it is issued an Attestato di Qualifica Professionale $^{100}$ or an Attestato di Frequenza ${ }^{101}$ with the certification of the Competences acquired (usually after passing an Exam). In the second case they are certified single competences.

\section{The Apprendistato}

The Apprendistato ${ }^{102}$ is an employment contract aimed at the training and employment of young people.

It is structured into three types with different learning purposes and different relationships with the Education and Training System: the Apprendistato per la Qualifica e il Diploma Professionale; the Apprendistato Professionalizzante or Contratto di Mestiere; the Apprendistato di Alta Formazione e di Ricerca.

The Apprendistato per la Qualifica e il Diploma Professionale is aimed at young people aged between 15 and 25 , which can be hired in all sectors of activity. It has a duration not exceeding three years if aimed at obtaining a Qualifica Professionale; up to four years if finalized to the acquisition of a Diploma Professionale ${ }^{103}$.

The Apprendistato Professionalizzante or Contratto di Mestiere is aimed at young people aged between 18 and 29.

\footnotetext{
${ }^{97}$ Inoccupato is someone who has never been employed; Disoccupato is someone who has lost his job or has ceased his activity. For further information please refer to: http://www.okpedia.it/inoccupato_disoccupato.

${ }^{98}$ Please see note 66.

${ }^{99}$ Regional Continuing Training.

${ }^{100}$ Certificate of Professional Qualification.

${ }^{101}$ Certificate of Attendance.

102 On 2012 was approved the State-Regions Agreement which defines the National System of Competences Certification Valid for the Apprendistato. For further information, please refer http://www.statoregioni.it/DettaglioDoc.asp?IDDoc=35970\&IdProv=10629\&tipo doc $=2 \& \mathrm{CONF}=$. For further information on the Apprendistato please refer to http://it.wikipedia.org/wiki/Apprendistato. Please see also note 30 and note 45 in this text.

103 State-Regions Agreement of 18 March 2012. For further information on the Accordo Stato-Regioni del 18 marzo 2012, please refer to: http://www.statoregioni.it/dettaglioDoc.asp?idprov=10439\&iddoc $=35481 \&$ tipodo $\mathrm{c}=18 \& \mathrm{CONF}=\mathrm{CSR}$.
} 
The Contratti Collettivi ${ }^{104}$ establish: the duration of the contract, which may not be longer than three years (five years for Craft Professions); professional standards of reference and modalities for providing Technical and Professional Training. The Regions prepare a Public Offering for the development of Basic and Transversal Competences for a maximum total number of hours of 120 in a three-year period. As a result of the Apprendistato Professionalizzante is possible to achieve a Qualifica Regionale and Competence Certifications or recognition of the Qualifica for contractual purposes.

The Apprendistato di Alta Formazione e di Ricerca is aimed at people aged between 18 and 29 hired in all areas of public and private activities. It is aimed at obtaining Qualifications (in the Istruzione Secondaria, the IFTS/ITS System and the University System), the acquisition of professional experiences in Research, the Praticantato ${ }^{105}$ for access to the professions that require registration in the Ordini Professionali [12].

\section{The Istruzione e Formazione degli Adulti}

Starting from the school year 2014/2015 the courses of Istruzione e Formazione degli Adulti ${ }^{106}$ are held in the Centri Provinciali per l'Istruzione degli Adulti ${ }^{107}$ (CPIA).

The CPIA are a type of Autonomous Educational Institution, organized in local networks of service, normally on a provincial basis.

The Centri Provinciali per l'Istruzione degli Adulti:

- have their own staff;

- have Collegial Bodies analogous to those of Educational Institutions;

- operate in close collaboration with the Local Self-Government and the world of work and professions;

- implement a Learning Offer structured on Learning Levels and aimed at the acquisition of a Qualification.

The pathways of the Istruzione degli Adulti include:

\footnotetext{
104 The Contratti Colletivi di Lavoro (Collective Labor Agreements) arise from the relationship between Trade Unions and Confederations of Employers, with the Government that often acts as a promoter or referee. These contracts set out the parameters and the basic rules to be followed by the Individual Employment Contracts. Often the Contratti Integrativi Aziendali (Corporate Contracts) have an integrative function for Collective Agreements, with which they are connected through a Pyramidal Contract System (Articulated Bargaining). For further information, please refer to [15].

105 The compulsory Tirocinio required for admission to an Ordine Professionale. Please see also note 66 and note 74 .

106 Adult Education and Training.

107 Provincial Centers for Adults' Education. The CPIAs replace the Centri Territoriali Permanenti per l'Istruzione e la Formazione nell'Età Adulta (CTP) established in 1997 and the Corsi Serali. The CPIA are defined by the Decree of the President of the Republic No. 263 of 29 October 2012, (http://www.gazzettaufficiale.it/eli/id/2013/02/25/13G00055/sg). On the operation of the CPIAs' System, please refer to [8], online available from: http://www.istruzione.lombardia.gov.it/wp-content/uploads/2010/04/10-passi-vers o-cpia.pdf.
}

- Percorsi di Istruzione di Primo Livello aimed at achieving the Final Qualification of the First Cycle of Education and the Certification attesting the acquisition of Basic Competences related to Compulsory Education;

- Percorsi di Istruzione di Secondo Livello aimed at achieving the Diploma di Istruzione Tecnica, Professionale e Artistica, carried out by the Educational Institutions in which the paths of Istruzione Tecnica, Professionale e Artistica work [9].

- Percorsi di Alfabetizzazione e Apprendimento della Lingua Italiana ${ }^{108}$, intended for foreign adults and aimed at acquiring a Qualification attesting the achievement of a level of proficiency in Italian Language not less than Level A2 of the Common European Framework of Reference for Languages approved by the Council of Europe [9].

In the Centers may enroll:

- adults, including foreigners, who have not completed Compulsory Education or who are not in possession of the Final Qualification of the First Cycle of Education;

- foreign adults of working age, even in possession of Qualifications obtained in the country of origin (for the Percorsi di Alfabetizzazione e Apprendimento della Lingua Italiana);

- those who have reached the age of sixteen and who are not in possession of the Final Qualification of the First Cycle of Education;

- those who have reached the age of fifteen, as a result of specific agreements among the Regioni and the Uffici Scolastici Regionali, within the limits of staff assigned and under specific motivated requirements.

The Centri Provinciali per l'Istruzione degli Adulti:

- carry out activities of Welcome and Guidance, aimed at defining the Patto Formativo Individuale ${ }^{109}$ (10\% of the corresponding total number of the path hours);

- recognize the Credits otherwise acquired by the student (Formal, Informal and Non-Formal Knowledge and Competences);

- customize the Study Path;

- provide a total number of hours equal to $70 \%$ of that of the corresponding ordinary Courses of Study;

- allow the remote fruition of a part of the planned Path ( $20 \%$ of the total number of hours).

\section{The Offer of Formazione Continua}

The Formazione Continua ${ }^{110}$ is intended for employed adults or adults who have lost their jobs and are looking for another job.

It is a Public and Private Offer.

The Formazione Continua of the Public System is assigned

\footnotetext{
${ }^{108}$ Pathways for Literacy and Learning of Italian Language.

109 Individual Learning Agreement. For further information on the Learning Agreement please refer to http://ec.europa.eu/education/opportunities/higher-education/quality-framework_e n.htm.

${ }^{110}$ Continuous Training.
} 
to:

- the Regioni and Province Autonome, which develop action strategies and program the offer using their own resources, even from the European Social Fund ${ }^{111}$, and the resources allocated by the Ministry of Labor;

- the Parti Sociali ${ }^{112}$, which operate mainly through the Fondi Paritetici Interprofessionali per la Formazione Continua $^{113}$, subject to supervision of the Ministry of Labor. To date, the Authorized Funds are twenty.

The main categories of subjects that deal with Continuous Training Activities in Public Funding are: Public and Private Companies and Organizations; Training Agencies; Institutional Bodies.

There are no principles in relation to the organization of Training Activities in terms of duration, modes and places of training [12].

The Private Offer can be:

- Corporate Training that does not use public funds and to the costs of which workers are not contributing (about $90 \%$ of corporate training) [12];

- delivered by Educational/Training Institutions (eg. Private Schools of Language and Computer Science issuing International Certificates with fee, Private Schools in the field of Aesthetics and Fashion, which allow the opening of Centers and Private Companies);

- linked to the Third Sector (supplied by Popular Universities, Universities of the Third Age or the Free Age, Voluntary Associations, Recreational and Cultural Associations, Social Cooperatives, Non-Governmental Organizations, Foundations).

\section{Prospects}

Within the Documento di Economia e Finanza ${ }^{114}$ (DEF) approved by the Consiglio dei Ministri ${ }^{115}$ on 8 April 2014, a section is dedicated to the National Reform Program. Of particular interest here: the Measures for the growth and development of Human Capital and the Reform of the Labor Market; National Reforms in Education, Training and Employment considered in the European context; Initiatives of the Government in response to the European Recommendations and in relation to the Objectives of the

\footnotetext{
111 The European Union Regional Policy, aims to equate the different levels of development among Regions and Member States in respect to Economic, Social and Territorial Cohesion Issues. This is realized through the use of Structural Funds (the Social Fund established in 1958 and the Regional Fund established in 1975) and the Cohesion Fund (established in 1994). For further information, please refer to [15].

112 Social Partners.

113 Joint Interprofessional Funds for Continuing Training. The Fondi Paritetici Interprofessionali finance sectoral and local training plans, that companies, either in single or associated form, decide to realize for their employees. They can also finance individual training plans, as well as additional preparatory activities, or anything else relating to training initiatives. The funds are set up and promoted by organizations representing businesses and workers, on the basis of voluntary contributions paid by member companies. For further information, please refer to [15].

114 Document of Economics and Finance.

115 Council of Ministers.
}

Europe 2020 Strategy concerning Labor Market, Employment Rate, Research and Development, School Dropouts, University Education.

With full knowledge of the impossible exhaustive discussion of all these arguments, it is nevertheless considered useful to provide an overview of the reformatory ferment currently underway ${ }^{116}$.

\subsection{National Reforms}

\subsubsection{Human Capital}

The Government considers School and Learning essential elements for the country's growth, and investments in Education, University and Research the firmer lever to achieve the objectives of Social Cohesion and Economic Development.

The main actions of the Government in this Area are related to:

- a Plan for schools safety and infrastructure improving, even through the implementation of the Anagrafe dell'Edilizia Scolastica ${ }^{117}$ (by July 2014);

- the improvement of the quality of the offer and the expertise of School and University Staff making it fully distributed and fully operational The National Evaluation System $^{118}$ (by September 2014);

- the reconstruction of a solid relationship among School, University and Research on the one hand and the world of Work and Business on the other (by 2014-2015);

- the spread of Language Competences, Digital Competences and Competences related to Entrepreneurship in the Education System;

- increasing the impact of measures for the Right to Study and promote the spread of Merit Systems in Universities;

- the internationalization of the System of Education and Research (by 2014) ${ }^{119}$.

\subsubsection{Labor Market}

The Government is currently working to implement an Organic Labor Reform (Jobs Act) for an effective rationalization of Recruitment Mechanisms and Contractual Forms and for the renewal and the increased efficiency of the Ammortizzatori Sociali ${ }^{120}$.

The main actions of the Government in this Area are related to:

\footnotetext{
${ }^{116}$ For any detail in relation to the Documento di Economia e Finanza 2014 please refer to: http://www.mef.gov.it/doc-finanza-pubblica/def/2014/. To follow the reform processes in place, including those in the field of Education, Training and Employment please refer to: http://passodopopasso.italia.it/.

117 Registry of School Buildings.

118 They are currently operating in this field, the Istituto Nazionale per la Valutazione del Sistema Educativo di Istruzione e di Formazione, INVALSI and the Agenzia Nazionale di Valutazione del Sistema Universitario e della Ricerca, ANVUR.

${ }^{119}$ For a summary sheet of ongoing actions in the areas of Labor and Human Capital please refer t6]: http://www.mef.gov.it/doc-finanza-pubblica/def/2014/documenti/DEF_Sezione_II I_Programma_Nazionale_di_Riforma_xParte_Ix_a.pdf. ${ }^{120}$ Social Benefits.
} 
- the simplification of the Contratti di Lavoro a Termine $^{121}$ and the Contratto di Apprendistato (by March 2014);

- the complete reorganization and unification of the multiple contractual forms (by July 2014);

- implementing the European Youth Guarantee Plan ${ }^{122}$ to promote employment and put young people in contact with the Labor Market (by May 2014);

- rationalization and integrated management of Labor Active and Passive Policies even including the creation of the Agenzia Nazionale per l'Impiego ${ }^{123}$ (by September 2014)

- the simplification of procedures and obligations associated with the creation and management of the Rapporto di Lavoro $^{124}$ (by July 2014).

\subsection{The National Reforms in the European Context: Education, Training and Employment}

The section dedicated to $A$ year of reforms opens showing how Italy and Europe follow a common path [6].

The Government points out that the actions undertaken are consistent with the commitments taken at the international level:

- Country Specific Recommendations (CSR)

- priorities set by the Annual Growth Survey (AGS)

- Europe 2020 Strategy.

The Country Specific Recommendations (CSR) are requests to adopt specific measures that each year the European Council expresses, after reviewing the National Reform Programmes (NRP) of the member countries and taking into account national structural problems. Among the measures required to Italy in 2013, that relating to the Labor Market (CSR No.4).

The Annual Growth Survey (AGS) is the starting point for the definition of priorities for action at National and European level. Among the priorities for 2014, to promote growth and competitiveness in the short and long term (No. 3) and to fight against unemployment and the social consequences of the crisis (No. 4).

Member States have committed themselves to achieving the objectives of the Europe 2020 Strategy in Employment, Research and Development and Innovation, Climate Change and Energy, Education, Poverty and Marginalization, for the purposes of an intelligent, sustainable and inclusive growth $^{125}$.

Within the Europe 2020 Strategy they were identified seven Flagship Initiatives (FI): European Digital Agenda (No. 1); Innovation Union (No. 2); Youth on the Move (No. 3); a Resource-Efficient Europe (No. 4); an Industrial Policy for the Globalization Era (No. 5); an Agenda for New Skills And

\footnotetext{
121 Fixed-Term Contracts.

${ }^{122}$ For further information on the European Youth Guarantee please refer to: http://ec.europa.eu/social/main.jsp?catId=1079.

${ }^{123}$ National Agency for Employment.

${ }^{124}$ Business Relationships.

125 For further information on the Europe 2020 Strategy please refer to: http://ec.europa.eu/europe2020/targets/eu-targets/index_it.htm.
}

Jobs (No. 6); European Platform Against Poverty (No. 7) ${ }^{126}$.

The main measures for Education and Training implemented by the Government are related to:

- the student's welfare (CSR No. 4; AGS No. 3; FI No. 3);

- textbooks (financing and facilities) (CSR No. 4; FI No. 3);

- Early School Leaving (contrast) (CSR No. 4; FI No. 6);

- the Offerta Formativa ${ }^{127}$ (including guidance and support) (CSR No. 4; FI No. 3);

- School construction (AGS No. 6);

- Teachers' Competences (including digital competences and percorsi scuola-lavoro ${ }^{128}$ ) (CSR n.4);

- University System and Research (promotion of merit and excellence) (CSR No. 4; FI No. 2).

The main measures for Labor implemented by the Government are related to:

- the Ammortizzatori in Deroga ${ }^{129}$ (refinancing and reform) (CSR No. 4; AGS No. 4);

- stimulating the creation of new jobs (CSR No. 4; AGS No. 4; FI n.6);

- the conciliation of work and family care time (CSR No. 4);

- the alternanza scuola-lavoro ${ }^{130}$ (CSR No. 4; FI No. 3);

- the Youth Guarantee Plan (CSR No. 4; FI No. 3);

- fight against the lavoro irregolare ${ }^{131}$ (CSR No. 4; AGS No. 4);

- the simplification of procedures (AGS No. 2).

\subsection{The Europe 2020 Strategy}

\subsubsection{Recommendation for the Labor Market}

As previously mentioned, the Recommendation No. 4 has as its object the Labor Market. In line with what is required at the European level, the Italian Government is committed to:

- implement the reform of the Labor Market;

- increasing the link between wages and productivity;

- increasing participation in the Labor Market, especially by young people;

- enhance Education and Vocational Training and Employment Services;

- prevent Early School Leaving and improve School quality and results;

- improve the services of personal care and after-school care;

\footnotetext{
126 For further information on the Flagship Initiatives please refer to: http://ec.europa.eu/europe2020/europe-2020-in-a-nutshell/flagship-initiatives/inde x_en.htm.

${ }^{127}$ Education and Training Offer.

${ }^{128}$ Please see note 130.

129 The Ammortizzatori in Deroga are compensations for income support granted on a temporary basis and through specific legislative measures, in favor of productive sectors or individuals who would be excluded from the ordinary protection provided against events such as the interruption or suspension of the business relationship. For further information, please refer to: http://www.wikilabour.it/ammortizzatori\%20deroga.ashx.

${ }^{130}$ Alternance Training. For further information on Alternance Training, please refer to: http://www.eqavet.eu/qa/gns/glossary/a/alternance-training.aspx

${ }^{131}$ Undeclared Work.
} 
- ensuring the effectiveness of social transfers.

In particular, in December 2013, the Government submitted to the European Union the Plan for Implementation of Youth Guarantee, which aims to: offer to the recipients the opportunity of a dedicated job interview; institutionalize in the Education System the Orientation to the world of work; encourage systematic actions against Not (engaged) in Education, Employment or Training (NEET) ${ }^{132}$; promote pathways towards Employment. The integrated management of information will be possible through the Informative Website ${ }^{133}$ and the Portal of Services ${ }^{134}$ (MDEDF 2014).

\subsubsection{Objectives for School, University, Research, Employment}

Among the objectives of the Europe 2020 Strategy of particular interest here, and that we have previously mentioned, we find:

- the reduction of Early School Leaving at a rate lower than $10 \%$ (Objective 6);

- the increase to $40 \%$ of those with Diploma di Istruzione Superiore (Tertiary Diploma) on the population between 30 and 34 years (Objective 7);

- the increase of public and private investment in Research and Development to 3\% of Gross Domestic Product (GDP) (Objective 2);

- the increase of the Employment Rate to $75 \%$ for those aged between 20 and 64 years (Objective 1).

In Italy, although Early School Leaving is in gradual decline, we are still far from the European objectives. In 2012 , the value is equal to $17.5 \%$ against $E U 27$ average of $12.8 \%$. Despite the progress made in recent years, in most of the Regions, especially in the South the goal of containment of dropouts below $10 \%$ seems distant.

For what concerns the impact of the population aged 30-34 holding a Tertiary Qualification, it is equal to $22.4 \%$. The necessary actions to achieve the objective, refer to those taken in response to recommendation No. 4.

University has over the years reduced its ability to attract young people. The lower proportion of Graduate Students may depend on several factors:

- the percentage of the population that concludes the Scuola Secondaria and accesses University,

- the proportion of the Diplomati who decide to enroll in University immediately,

- the proportion of the population who decides to enroll in University Courses years away from the Diploma,

- the proportion of students who complete successfully the Cycle of Studies [6].

An overall analysis of the data shows:

- a percentage of younger graduates in line with the European average;

- an average age of registered which is the lowest among

\footnotetext{
132 For further information please on the NEET, please refer to: http://www.eurofound.europa.eu/emcc/labourmarket/youth.htm.

${ }^{133} \mathrm{http}: / / \mathrm{www}$.garanziagiovani.gov.it.

${ }^{134} \mathrm{http}: / / \mathrm{www} . c l i c l a v o r o . g o v . i t$.
}

European countries;

- low inflow of foreign students and students in mature age significant, but not sufficient by itself to explain the low number of graduates.

It seems rather, that the major cause should be sought in the path of University Studies, so for example, at a distance of nine years from the first registration, only $55 \%$ of students achieve the Qualification $^{135}$ [6].

Among the measures introduced by the Government in this sector:

- a new type of Borsa di Studio ${ }^{136}$ for students who have achieved excellent study results;

- the increase of the Supplementary State Fund for granting the Borse di Studio to University students;

- the reduction in duration of Specialized Training Courses for Physicians in the academic year 2013/2014;

- the increase of the Fondo per il Finanziamento Ordinario delle Università (FFO) ${ }^{137}$ and the Fund for financing Research Institutions supervised by the MIUR;

- the simplification of the University Call Procedure for Scholars winners of Programs of High Quality Research;

- the simplification of the Funding System for Universities: the $3 / 5$ of the incentives will be distributed according to the results of the ANVUR Evaluation and 1/5 will award Recruitment Policies, which are also measured by the ANVUR;

- the modification of the criteria for initial and periodic accreditation of the Courses of Study and of the Sedi di Studio ${ }^{138}$.

In relation to the investment in Research and Development, for 2012 is expected a moderate growth, with an increase in public spending and a decrease in the private one, in line with the trend registered in 2011. The eighteenth Italy's position with respect to the EU27 average of 2011 would remain unchanged in 2012.

Public resources invested in Research constitute about $0.52 \%$ of the GDP. To the lesser resources invested it corresponds a lower number of Researchers and a lower potential for Innovation, although overall, Universities and Research Institutes show a quality of scientific publications comparable to that of major European countries. Furthermore, in relation to the resources invested and the number of Researchers, the quantity and quality of Research is high ${ }^{139}$ [6].

\footnotetext{
135 For further information on University current trends, please refer to: http://www.anvur.org/attachments/article/644/Rapporto\%20ANVUR\%202013_U NIVERSITA\%20e\%20RICERCA_integrale.pdf.

${ }^{136}$ Please see note 78.

${ }^{137}$ University Ordinary Fund. The Fondo per il Finanziamento Ordinario delle Università is a state fund that covers the cost of the operation and the institutional activities of Universities, and includes resources for the payment of salaries to the Teaching, Research and Non-Teaching Staff. For further information, please refer to [15].

138 Please see note 77.

${ }^{139}$ Please see note 135
} 
Among the measures to stimulate spending on Research and Development:

- tax credit for companies that invest;

- facilities for Entry Visas and Residence Permits associated with Innovative Start-Ups;

- support for the development of Fundamental Research Activities and Industrial Research;

- employment of Researchers and Technologists of very high Scientific Qualification in Research Institutions supervised by the MIUR;

- financing of 67 projects in Futuro in Ricerca ${ }^{140}$ (FIR) 2013

- approval of 141 Progetti di Ricerca di Interesse Nazionale (PRIN), Bando ${ }^{141}$ 2012;

- financing of the new Bando for the Scientific Independence of Young Researchers (SIR);

- review of current legislation on the management of the Fund for Investment in Scientific and Technological Research:

- allocation for Research and Development of the Amministrazioni Pubbliche ${ }^{142}$ of the Convergence Regions $^{143}$;

- facilitation of the Horizon 2020 Research and Development Projects;

- financing of Research and Development Programs in the Aviation Sector;

- allocation of resources for 105 projects of Social Innovation;

- support of Innovative Activities and Research of companies through the Programma Operativo Nazionale $(\mathrm{PON})^{144}$ Research and Innovation;

- upgrading the infrastructure of Public Research.

In 2013, in Italy, the employment rate is slightly reduced, increasing the distance with the European objective.

The measures based on the Labor Market Active Policies affect men more than women and are implemented especially in the North. They are more widespread in the South measures relating to the Assunzioni Agevolate di Disoccupati $^{145}$, the recipients of the Cassa Integrazione Guadagni Straordinaria ${ }^{146}$ (CIGS), the Borse di Lavoro ${ }^{147}$

\footnotetext{
140 For further information on the Futuro in Ricerca, please refer to: http://futuroinricerca.miur.it/.

${ }^{141}$ Please see note 95.

142 Public Sector Entities.

${ }^{143}$ In the European Union 2007-2013 Programming the Italian Regioni of Calabria, Campania, Puglia and Sicilia are included in the Convergence Objective aimed at speeding up the convergence of the Member States and Regions lagging behind in development, by improving conditions for growth and employment. For further information, please refer to [15].

144 National Operational Programs. Please see note 107.

145 Facilitated Recruitment of Unemployed.

146 The Cassa Integrazione Guadagni Straordinaria is an economic measure provided by the Istituto Nazionale della Previdenza Sociale (INPS) to supplement or replace the remuneration of workers in order to cope with business crisis or to allow the companies to deal with restructuring, reorganization, reconvertion. For further information, please refer to: http://www.inps.it/portale/default.aspx?itemdir=5796.

${ }^{147}$ Law No. 196 of 1997. For further information on the Law establishing the Borse di Lavoro please refer to: http://www.camera.it/parlam/leggi/971961.htm.
}

and the Contratti di Inserimento ${ }^{148}$ [6].

The necessary actions to achieve the objective, refer to those taken in response to recommendation No. 4 .

\section{Conclusions}

In this paper we take a picture of the Italian Education and Training System crossed by the new wave of reform. In particular, after outlining the existing mechanisms of governance, we examine the articulation and the operation of the Scuola dell'Infanzia, the Primo Ciclo di Istruzione, the Secondo Ciclo di Istruzione and the Istruzione Superiore. Afterwards, we consider the Formazione Professionale Iniziale, the Apprendistato, the Istruzione e Formazione degli Adulti and the Formazione Continua.

Finally, we cast a glance towards the future, indicating the prospects that lie ahead. To this end we present the actions that the Government has started and that it intends to pursue in the fields of Education, Training and Employment, in the context of European Policies.

The work presented has required special concentration caused by the objective difficulty to find the way in a constantly shifting scene. However, in that same landscape we find more and more the will and the active pursuit of transparency and intelligibility, which is at the same time admission of plurality and openness to the outside. Obviously, to this is not alien to the role of the European Union, which over the years has given rise to a certain type of Culture, which is already the daily of the new generations and that slowly but inexorably, is becoming heritage of all citizens and of our political representatives.

\section{References}

[1] Agenzia Nazionale di Valutazione del Sistema Universitario e della Ricerca, Rapporto sullo Stato del Sistema Universitario e della Ricerca 2013, 2014. Online available from: http://www.anvur.org/attachments/article/644/Rapporto\%20A NVUR\%202013_UNIVERSITA\%20e\%20RICERCA_integral e.pdf.

[2] D. Ianes, S. Cramerotti, Insegnare domani nella scuola primaria. Manuale per una preparazione metacognitiva efficace, Eds. Trento: Erickson, 2013. ISBN 978-88-590-0248-2.

[3] Eurypedia, European Encyclopedia on National Education Systems, "Italy. Ongoing Reforms and Policy Developments", June 2014. Online available from: https://webgate.ec.europa.eu/fpfis/mwikis/eurydice/index.php/ Italy:Ongoing_Reforms_and_Policy_Developments.

[4] Law No. 62 of 10 March 2000. Online available from: http://archivio.pubblica.istruzione.it/news/2002/prot245_02.sh tml.

\footnotetext{
148 The Contratto di Inserimento aims to insert, or reinsert, in the Labor Market certain categories of persons through an Individual Project adapting the individual professional competences to a particular business setting. For further information, please refer to: http://www.inps.it/portale/default.aspx ?itemdir=6352.
} 
[5] Ministero del Lavoro e delle Politiche Sociali, "Articolazione degli uffici”, 2014. Online available from: http://www.lavoro.gov.it/Ministero/AreaTrasparenza/Organizz azione/ArticolazioneUffici/Pages/organigr_img.aspx.

[6] Ministero dell'Economia e delle Finanze, "Sezione III, Programma Nazionale di Riforma. Parte I, La strategia nazionale e le principali iniziative", in Documento di Economia e Finanza 2014, April 2014. Online available from: http://www.mef.gov.it/doc-finanza-pubblica/def/2014/docume nti/DEF_Sezione_III_Programma_Nazionale_di_Riforma_xP arte_Ix_a.pdf.

[7] Ministero dell'Economia e delle Finanze, "Programma Nazionale di Riforma. Parte II, Gli squilibri nazionali e le riforme in dettaglio", in Documento di Economia e Finanza 2014, April 2014. Online available from: http://www.mef.gov.it/doc-finanza-pubblica/def/2014/docume nti/DEF_Sezione_III_Programma_Nazionale_di_Riforma_xP arte_IIx_a.pdf.

[8] Ministero dell'Istruzione, dell'Università e della Ricerca. Dipartimento per l'Istruzione. Direzione Generale per l'Istruzione e Formazione Tecnica Superiore e per i Rapporti con i Sistemi Formativi delle Regioni. "Dieci passi verso i CPIA...", Progetti assistiti a livello nazionale, Nota 4241, July 2013. Online available from: http://www.istruzione.lombardia.gov.it/wp-content/uploads/20 10/04/10-passi-verso-cpia.pdf.

[9] Ministero dell'Istruzione, dell'Università e della Ricerca. Direzione Generale per gli Affari Internazionali. Indire, Unità Italiana di Eurydice. "Il sistema educativo italiano 2013". I quaderni di Eurydice No. 29, December 2013. Online available from: http://www.indire.it/lucabas/lkmw_file/eurydice///Quaderno_p er_web_definitivo.pdf.

[10] Ministero dell'Istruzione, dell'Università e della Ricerca, Ministero del Lavoro e delle Politiche Sociali. "Relazione nazionale 2011 sull'attuazione del Quadro strategico per la cooperazione europea nell'istruzione e nella formazione (IF 2020)". Formazione Orientamento Professionale, FOP Speciale, Year 11, No. 3. ISSN 1591-7738. Online available from:

http://europalavoro.lavoro.gov.it/Documents/fop-spec-3-2011. pdf.

[11] Parlamento Europeo e Consiglio dell'Unione Europea, Raccomandazione del Parlamento Europeo e del Consiglio del 18 dicembre 2006 relativa a competenze chiave per l'apprendimento permanente, Gazzetta Ufficiale dell'Unione Europea, December 2006. Retrieved from http://eur-lex.europa.eu/LexUriServ/LexUriServ.do?uri=OJ:L: 2006:394:0010:0018:it:PDF

[12] Presidenza del Consiglio dei Ministri. Conferenza Permanente per i Rapporti tra lo Stato, le Regioni e le Province Autonome di Trento e Bolzano. Accordo sulla referenziazione del sistema italiano delle qualificazioni al quadro europeo delle qualifiche per l'apprendimento permanente (EQF) di cui alla Raccomandazione del Parlamento Europeo e del Consiglio del 23 aprile 2008. Repertorio atti No. 252, December 2012. Online available from: http://www.statoregioni.it/Documenti/DOC_038876_DOC_03 8876_252\%20csr\%20-\%201\%20bis.pdf

[13] S. Savelli, "Istruzione e formazione nel secondo millennio: gli Stati Uniti" in Orientamenti Pedagogici, Eds. Erickson, in press.

[14] Savelli S. "Istruzione e formazione nel secondo millennio: la formazione dell'insegnante negli Stati Uniti", unpublished.

[15] S. Savelli, "Italian Lifelong Learning in Europe: Notes to the Second Millennium", in Journal of Education and Training Studies, Vol. 2, No. 2, Eds. Redframe Publishing, January 24, 2014. ISSN 2324-805X (Print). ISSN 2324-8068 (Online). Online available from: http://redfame.com/journal/index.php/jets/article/view/303/27 8.

[16] S. Savelli, "Teaching and Learning in the Society of Continuing Education and Training", in Universal Journal of Educational Research, Vol. 2 No. 5, 2014. DOI: 10.13189/ujer.2014.020503. Online available from: http://www.hrpub.org/download/20140405/UJER3-19502204. pdf. 